J. Electroanal. Chem., 240 (1988) 171-183

Elsevier Sequoia S.A., Lausanne - Printed in The Netherlands

\title{
CHEMICAL ANALYSIS OF THE IONIC CONTENT OF HYDROUS IRIDIUM OXIDE FILMS
}

PETER G. PICKUP * and VIOLA I. BIRSS

Chemistry Department, University of Calgary, Calgary, Alberta T2N IN4 (Canada)

(Received 28th July 1986; in revised form 29th June 1987)

ABSTRACT

Potassium, lithium and fluoride ion analyses, together with $\mathrm{pH}$ measurements, have been used to elucidate the role of ions from the electrolyte solution in the charging and discharging of Ir oxide films in aqueous media. The charge on the oxide has been found to vary with both $\mathrm{pH}$ and oxidation state. The oxidized form ( $\operatorname{Ir}(\mathrm{IV}))$ is anionic in base and approximately neutral in acid. The reduced form ( $\operatorname{Ir}(\operatorname{III}))$ is cationic in acid and slightly anionic in base. Both forms carry little charge in near-neutral solutions. As a consequence of these variations, both $\mathrm{H}^{+}$(or $\mathrm{OH}^{-}$) and counterions $\left(\mathrm{M}^{+}\right.$or $\mathrm{X}^{-}$) are involved in the redox reactions of Ir oxide, and the $\mathrm{pH}$ dependence of the average formal potential of the $\operatorname{Ir}(\mathrm{IV}) / \operatorname{Ir}(\mathrm{III})$ couple varies with $\mathrm{pH}$. Voltammetry and ion analysis in unbuffered neutral solutions has revealed a transient insertion of $\mathrm{M}^{+}$ions during oxide reduction, due to $\mathrm{pH}$ changes within the oxide.

\section{INTRODUCTION}

There has been some controversy in recent years concerning the mechanism of the electrochemical oxidation and reduction of hydrous iridium oxide films [1-7]. In order for electroneutrality to be maintained within the oxide, the oxidation or reduction of the Ir centres within such films must be accompanied by the movement of ions between the oxide film and the electrolyte solution. McIntyre and co-workers $[1,4]$ favour a proton-electron dual injection/expulsion mechanism for oxide reduction/oxidation, whereas Shay and co-workers [2] favour a hydroxide expulsion/injection mechanism for oxide reduction/oxidation.

Burke and Whelan [3] have argued that, on the basis of their observed ca. $90 \mathrm{mV}$ per $\mathrm{pH}$ unit dependence of the potential of the $\operatorname{Ir}(\mathrm{IV}) /(\mathrm{III})$ couple in the oxide,

\footnotetext{
* Present address: Department of Chemistry, Memorial University of Newfoundland, St. John's, Newfoundland A1B 3X7, Canada.

0022-0728/88/\$03.50 C두 1988 Elsevier Sequoia S.A.
} 
three protons are injected into (or $\mathrm{OH}^{-}$ions are expelled from) the oxide for each two electrons injected during film reduction. These authors have used the reaction

$2\left[\mathrm{IrO}_{2}(\mathrm{OH})_{2} \cdot 2 \mathrm{H}_{2} \mathrm{O}\right]^{2-}+2 e^{-}+3 \mathrm{H}^{+}=\left[\mathrm{Ir}_{2} \mathrm{O}_{3}(\mathrm{OH})_{3} \cdot 3 \mathrm{H}_{2} \mathrm{O}\right]^{3-}+3 \mathrm{H}_{2} \mathrm{O}$

to describe the electrochemistry of Ir oxide in acidic solutions [6].

Reaction (1) could also be written in terms of hydroxide expulsion, which would be more appropriate for alkaline solutions. In either case, it can be clearly seen in reaction (1) that the charge on the oxide becomes less negative during reduction. To maintain electroneutrality within the oxide film, either some other anion (X) must enter, or some other cation (M) must leave the oxide during reduction.

In this paper, we report the results of a study of the involvement of $\mathrm{H}^{+}$(or $\left.\mathrm{OH}^{-}\right), \mathrm{Li}^{+}, \mathrm{Na}^{+}, \mathrm{K}^{+}, \mathrm{Et}_{4} \mathrm{~N}^{+}$and $\mathrm{F}^{-}$ions in the electrochemistry of hydrous Ir oxide films in HF, MX and MOH solutions. By analysing the alkali metal ion and fluoride ion content of films which have been oxidized or reduced in these solutions, and by measuring $\mathrm{pH}$ changes in the solution as Ir oxide films are oxidized and reduced, we have been able to determine the extent to which these ions are involved in the electrochemical reaction as a function of solution composition and $\mathrm{pH}$.

There are several important new findings from this work. First, we have demonstrated the involvement of alkali metal ions $\left(\mathrm{M}^{+}\right)$in the charging and discharging of Ir oxide in basic aqueous solutions. Secondly, we have demonstrated that, in acidic solutions, anions enter the oxide during reduction and leave during oxidation. The involvement of alkali metal ions in near-neutral solutions has also been demonstrated.

Measurements of the ionic content of Ir oxide films have been reported previously by McIntyre et al. [4]. These authors have shown that $\mathrm{H}^{+}$is inserted into the oxide during its reduction in aqueous acid solutions. These authors also showed that alkali metal ion insertion could occur during Ir oxide reduction in non-aqueous solvents. A study of the ion content of $\mathrm{Ni}$ hydroxide films has also been reported previously [8].

\section{EXPERIMENTAL DETAILS}

\section{Electrochemical equipment}

All electrochemical experiments were performed in conventional three-compartment glass cells at room temperature under argon. The working electrode for most of the experiments was a piece of iridium foil (ca. $10 \times 3 \times 0.05 \mathrm{~mm}$; $99.9 \%$ purity; Metal Crystals and Oxides Ltd., Great Britain) which had been polished with $1 \mu \mathrm{m}$ diamond paste. An iridium wire working electrode $(0.5 \mathrm{~mm}$ dia.; $99.9 \%$; Johnson Matthey) was used for obtaining the voltammograms shown in Fig. 2.

The Ir foil electrode had a small hole near the top which was used to hang it from a Pt wire, which was sealed in glass. Only the bottom two thirds of the foil was immersed into the electrolyte. The electrode area was approximately $0.4 \mathrm{~cm}^{2}$. This 
area, and all electrode areas used in the calculation of current and charge densities, are geometric areas.

The reference electrode was a SCE (Fisher) containing sat. $\mathrm{NaCl}$ (SSCE) and all potentials are quoted with respect to this electrode. An EG\&G PARC 173 potentiostat was used with a PARC 175 Universal Programmer and a PARC 179 digital coulometer. Voltammograms were recorded on a Hewlett-Packard 7044A X-Y recorder.

All reagents, except $\mathrm{Et}_{4} \mathrm{NClO}_{4}$ (Fluka), were Fisher Certified or Reagent ACS grade and were used as received.

Oxide growth

Before oxide growth, the electrode was cleaned electrochemically (to remove any oxide remaining from the previous experiment) at ca. $+1.9 \mathrm{~V}$ in ca. $1 \mathrm{M} \mathrm{H}_{2} \mathrm{SO}_{4}$ for ca. 5 min. Occasional pulses of potential into the hydrogen evolution region (e.g. $-0.7 \mathrm{~V}$ ) were found to reduce the time required to remove the oxide. Ir oxide films were grown in $0.5 \mathrm{M} \mathrm{H}_{2} \mathrm{SO}_{4}$ using 900 cycles of potential pulses between the voltage limits of -0.26 and $+1.24 \mathrm{~V}$ vs. SSCE at $0.5 \mathrm{~Hz}$. This yields films that are approximately $1 \mu \mathrm{m}$ in thickness and have a charge capacity of ca. $70-90 \mathrm{mC} / \mathrm{cm}^{2}$ $[9,10]$.

Analysis of ions

The alkali metal ion and fluoride ion contents of Ir oxide films were determined by exchanging the ion of interest into a suitable aqueous solution which was then analysed. The general procedure was as follows.

The oxide film, grown to a particular thickness, was first equilibrated in the medium of interest by cycling the electrode potential at a scan rate of $10 \mathrm{mV} / \mathrm{s}$, so that the oxide was repeatedly oxidized and reduced. The oxide was then fully oxidized (or reduced) at a constant potential for several minutes. Then its potential was stepped so as to reduce (or oxidize) the film fully and the charge passed was recorded. The electrode was disconnected, removed from the cell, rinsed with acetone or methanol and soaked dry with a tissue. The ion of interest was extracted by ion-exchange into a small volume $(2-10 \mathrm{ml})$ of aqueous solution which was then analysed. The electrolyte was generally not stirred during these experiments.

In all cases, it was desirable to relate the ion content of the film to the charge passed during the preceding electrochemical reaction. The results are therefore presented as the ratio of the number of a particular ion found within the film, or found to be involved in the electrochemical reaction, to the number of electrons passed during the electrochemical reaction (ion $/ e^{-}$). Voltage limits were chosen such that the charge passed was equivalent to all of the Ir sites within the film changing their oxidation state between $\operatorname{Ir}(\mathrm{III})$ and $\operatorname{Ir}(\mathrm{IV})$ [9]. Thus the ion $/ e^{-}$ratio is approximately equivalent to the ion/Ir ratio. 
$\mathrm{Li}^{+}$and $\mathrm{K}^{+}$analysis

These ions were extracted from $\mathrm{Ir}$ oxide films that had been cycled in $\mathrm{Li}^{+}$or $\mathrm{K}^{+}$

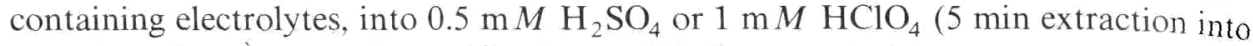
$10 \mathrm{ml}$ ) and analysed using a Heath EU-703 flame emission spectrometer with a stoichiometric acetylene/air flame. $\mathrm{Li}^{+}$was determined at $671 \mathrm{~nm}$ using 0.02 to 0.25 ppm $\mathrm{Li}^{+}\left(\mathrm{LiClO}_{4}\right)$ standards in $0.5 \mathrm{mM} \mathrm{H} \mathrm{H}_{2} \mathrm{SO}_{4}$ or $1 \mathrm{mM} \mathrm{\textrm {HClO } _ { 4 }}$. $\mathrm{K}^{+}$was determined at $767 \mathrm{~nm}$ using 0.05 to $0.50 \mathrm{ppm} \mathrm{K} \mathrm{K}^{+}\left(\mathrm{KClO}_{4}\right.$ or $\left.\mathrm{KCl}\right)$ standards in 1 $\mathrm{m} M \mathrm{HClO}_{4}$.

A number of experiments were carried out initially to optimize the analysis procedure. It was found that washing the electrode with water before the extraction into the acid solution resulted in low $\mathrm{M}^{+}$results (compared to results obtained with a methanol wash, which are believed to be the most accurate). This was presumably due to rapid leaching of $\mathrm{M}^{+}$from the oxide into the water. Washing with acetone, however, yielded high $\mathrm{M}^{+}$results, particularly when the electrode had just been removed from a $\mathrm{LiOH}$ solution. This was attributed to precipitation of $\mathrm{MOH}$ from the adhering electrolyte solution onto the oxide surface during washing, since control experiments with a bare Ir foil that had been soaked in the LiOH solution and washed with acetone gave a significant $\mathrm{Li}^{+}$analysis. Methanol was found to be the most suitable solvent for washing off excess electrolyte, as these leaching and precipitation problems were minimized with this solvent.

$F^{-}$analysis

$\mathrm{F}^{-}$was extracted from $\mathrm{Ir}$ oxide films which had been cycled in $\mathrm{F}^{-}$containing electrolytes and rinsed with acetone, into $2 \mathrm{ml}$ of a buffer solution (TISAB) consisting of $0.1 \mathrm{M}$ acetate + acetic acid ( $\mathrm{pH}$ 5.3) and $0.1 \mathrm{M} \mathrm{NaCl}$. An Orion 94-09 fluoride-sensing electrode was used with a SCE (Fisher) reference electrode and a Fisher $825 \mathrm{MP} \mathrm{pH}$ meter. The four-point calibration facility of the meter was used with $1.00 \times 10^{-4}, 3.16 \times 10^{-5}, 1.00 \times 10^{-5}$ and $3.16 \times 10^{-6} \mathrm{M} \mathrm{KF}$ standards in TISAB.

\section{pH measurements}

The $\mathrm{H}^{+}$and $\mathrm{OH}^{-}$contents of $\mathrm{Ir}$ oxide films were not measured by a direct method. Instead, changes of the electrolyte $\mathrm{pH}$ during oxidation and reduction of the oxide were used to measure the amount of $\mathrm{H}^{+}$(or $\left.\mathrm{OH}^{-}\right)$consumed or released. The small quantities of $\mathrm{H}^{+}$or $\mathrm{OH}^{-}$involved in the electrochemical reactions limited the applicability of this type of experiment to solutions in the $\mathrm{pH}$ range of 4 to 10 .

A Fisher 13-639-93 combination $\mathrm{pH}$ electrode was inserted into the electrochemical cell and the cell solution, which ranged in $\mathrm{pH}$ from 4.8 to 9.0, was stirred constantly with a stream of Ar.

In a typical experiment, a freshly grown oxide film was first equilibrated by cycling the electrode potential at a scan rate of $10 \mathrm{mV} / \mathrm{s}$, so that the oxide was repeatedly oxidized and reduced. The oxide was then fully oxidized at a constant potential of $+0.7 \mathrm{~V}$ for several minutes after which the cell was switched off. The $\mathrm{pH}$ was recorded once it had stabilized (i.e. after several minutes). The film was then 
reduced fully at $-0.7 \mathrm{~V}$ and both the charge passed and the final $\mathrm{pH}$ were recorded. This was repeated for oxidation of the film.

After charge and $\mathrm{pH}$ data had been collected for a number of potential steps, the system was calibrated by the addition of 20 or $50 \mu 1$ aliquots of $1 \mathrm{~m} M \mathrm{HX}$ to the cell solution in order to reproduce the $\mathrm{pH}$ range encountered in the experiment. This calibration was required because of buffering of the solution by atmospheric $\mathrm{CO}_{2}$ and because it was difficult to determine the electrolyte volume accurately. Using the calibration plot, it was possible to relate $\mathrm{pH}$ changes caused by the electrochemical reactions of the Ir oxide (reaction 1) accurately to the quantity of $\mathrm{H}^{+}$released or consumed.

There were no significant differences between the $\mathrm{H}^{+} / e^{-}$ratios for oxidation or reduction. Therefore, the reported results (Table 1, below) are an average of several oxidation and reduction experiments.

\section{RESULTS AND DISCUSSION}

\section{Cyclic voltammetry}

Figure 1 shows some typical cyclic voltammograms of Ir oxide in $0.2 \mathrm{M} \mathrm{HF}$ (Fig. 1A) and $0.1 \mathrm{M} \mathrm{KOH}$ (Fig. 1B). These voltammograms are similar to those in the literature for Ir oxide in other strongly acidic [1] and strongly basic [11] aqueous solutions. The shift of the Ir oxide redox waves with $\mathrm{pH}$ (close to $1.5 \times 2.3 R T / F$ or $88.5 \mathrm{mV}$ ) seen in Fig. 1 is consistent with the reported $\mathrm{H}^{+} / e^{-}$ratio of ca. 1.5 [3]. The formal potential for the main (largest) wave, $E^{{ }^{\prime \prime}}$, can be given by [12]:

$E^{\circ \prime} / \mathrm{V}$ vs. $\mathrm{SSCE}=0.69-0.089 \mathrm{pH}$

Shay and co-workers [2] have reported that the $\mathrm{pH}$ dependence of $\mathrm{Ir}$ oxide voltammetric waves is $59 \mathrm{mV} / \mathrm{pH}$ unit. However, it is clear from the voltammograms reported by Dautremont-Smith and co-workers [5] that the former authors [2] have incorrectly tracked the Ir oxide peaks through the $\mathrm{pH} 4$ to 10 range. The latter authors [5] report a response of $\sim 85 \mathrm{mV} / \mathrm{pH}$ unit.

Since Ir oxide oxidation and reduction involves $\mathrm{H}^{+}$or $\mathrm{OH}^{-}$ions, particularly in acidic and basic solutions, we suspected that other reactions might also occur in neutral solutions, where the concentration of these ions is very low. In particular, it was thought that when the alkali metal ion $\left(\mathrm{M}^{+}\right)$concentration was significantly higher than that of either $\mathrm{H}^{+}$or $\mathrm{OH}^{-}$, then $\mathrm{M}^{+}$insertion might occur during oxide reduction, as it does in non-aqueous media $[4,13]$. To investigate this possibility, voltammograms of Ir oxide in some near-neutral solutions were obtained. Figure 2 shows typical voltammograms of Ir oxide in neutral aqueous $\mathrm{Et}_{4} \mathrm{NClO}_{4}, \mathrm{LiClO}_{4}$ and $\mathrm{NaClO}_{4}$ solutions. $\mathrm{Et}_{4} \mathrm{NClO}_{4}$ was used here as a control electrolyte, since $\mathrm{Et}_{4} \mathrm{~N}^{+}$is much larger than the alkali metal ions and therefore is less likely to insert into Ir oxide.

It should be noted that buffering of the solution would have added to the complexity of this study, in that the ions of the buffer, e.g. acetate, phosphate, borate etc. could also have been involved in maintaining charge neutrality within the 

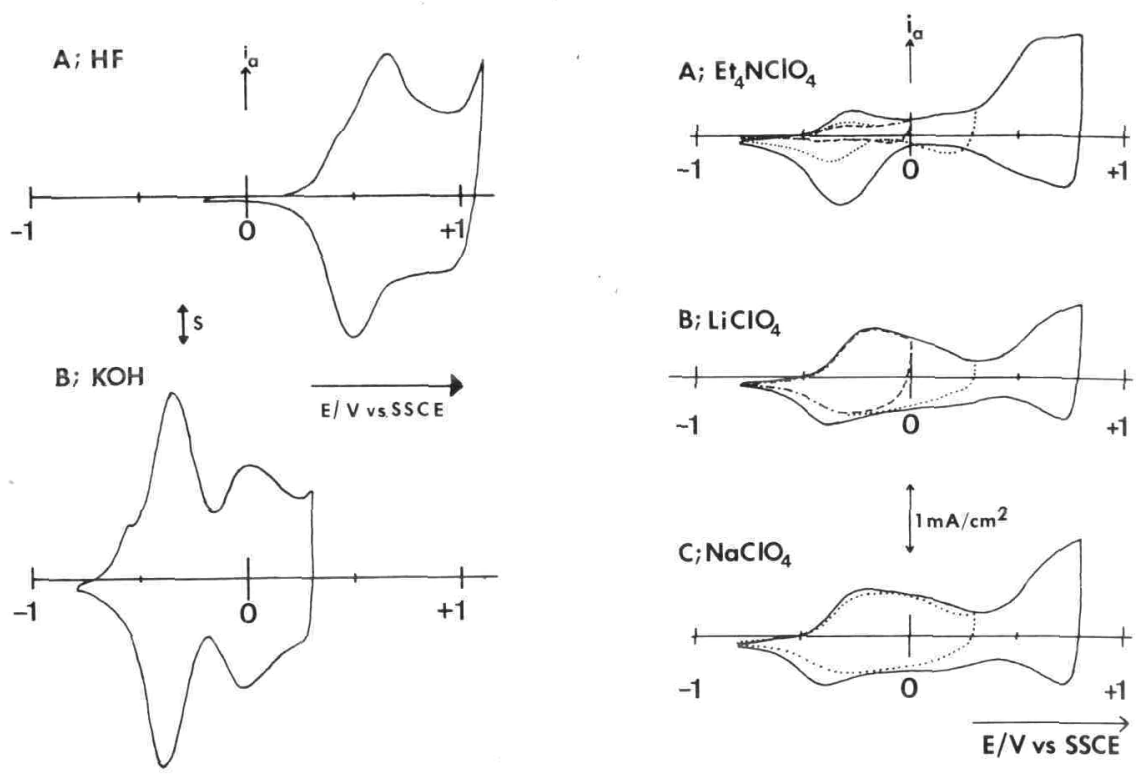

Fig. 1. Cyclic voltammograms of hydrous Ir oxide films (ca. $1 \mu \mathrm{m}$ thick) in $0.2 M \mathrm{HF}$ (A) and in $0.1 M$ $\mathrm{KOH}(\mathrm{B})$. Scan rate $=10 \mathrm{mV} / \mathrm{s}$. Sensitivity $(S)=0.50\left(\right.$ A) or $0.25\left(\right.$ B) $\mathrm{mA} / \mathrm{cm}^{2}$.

Fig. 2. Cyclic voltammograms of a hydrous Ir oxide film (ca. $0.1 \mu \mathrm{m}$ thick) in $0.1 \mathrm{M} \mathrm{Et}_{4} \mathrm{NClO}_{4}$ (A), 0.1 $M \mathrm{LiClO}_{4}$ (B) and $0.1 \mathrm{M} \mathrm{NaClO}_{4}$ (C). Scan rate $=100 \mathrm{mV} / \mathrm{s}$. Dotted and dashed lines show voltammograms with less positive upper potential limits (see text). $I R_{\mathrm{u}}$ compensation was used.

oxide. This would then have made it necessary to analyze for at least three ions in each experiment, thus making the interpretation of the results more difficult. For this reason, unbuffered near-neutral solutions were utilized in most of this work.

In a near-neutral $\mathrm{Et}_{4} \mathrm{NClO}_{4}$ solution, the main oxidation and reduction peaks for Ir oxide would have been expected to appear at ca. + $0.1 \mathrm{~V}$ vs. SSCE (eqn. (2), for $\mathrm{pH}=7$ ), if the main reaction under these conditions is that represented by reaction (1). However, no peaks appear near this potential in Fig. 2A. This is probably due to the fact that in this non-buffered near-neutral solution, the consumption and production of protons during the electrochemical reduction and oxidation of Ir oxide, respectively (reaction 1), would cause the $\mathrm{pH}$ of the solution within the film to change throughout the voltage scan, and hence the voltammetric peaks are shifted accordingly [1].

Consider the voltammetric behaviour of Ir oxide in aqueous $\mathrm{Et}_{4} \mathrm{NClO}_{4}$ (Fig. 2A $(-)$ ). At the end of the negative scan $(-0.8 \mathrm{~V})$, the solution within the oxide film would be basic due to the consumption of $\mathrm{H}^{+}$during reduction of the film. Thus, during the positive scan, the oxide begins to oxidize at $-0.5 \mathrm{~V}$ and a small current peak is seen at $-0.28 \mathrm{~V}$. This is close to the predicted potential of the anodic peak for Ir oxide at a $\mathrm{pH}$ of 11 (eqn. 2), indicating that this is the 
approximate $\mathrm{pH}$ within the oxide film at this point. However, as the film is oxidized further, $\mathrm{H}^{+}$is released and the $\mathrm{pH}$ is expected to decrease, thus shifting the oxidation potential of Ir oxide in the positive direction. As a consequence, the bulk of the film is oxidized at a potential $\left(E_{\mathrm{pa}}=0.64 \mathrm{~V}\right)$ which would be characteristic of Ir oxide oxidation at $\mathrm{pH} \sim 1$.

In the subsequent negative scan, film reduction commences at a potential $\left(E_{\mathrm{pc}}=0.70 \mathrm{~V}\right)$ corresponding to a $\mathrm{pH}$ of ca. 0 . Further film reduction causes the $\mathrm{pH}$ to rise in the interior of the film as protons are consumed (reaction 1) and so the bulk of the oxide reduces at a more negative potential $(-0.33 \mathrm{~V})$, corresponding to a $\mathrm{pH}$ of ca. 11.

The above interpretation of the voltammogram shown in Fig. 2A ( - ) is supported by the effect of decreasing the upper potential limit, which is also shown in Fig. 2A. When the positive scan was reversed at $+0.3 \mathrm{~V}(\cdots)$ ) the reduction peak at ca. $-0.4 \mathrm{~V}$ was greatly diminished because only a small fraction of the oxide had been oxidized. At the beginning of the next positive scan $(\cdots \cdots)$, the solution within the oxide was therefore less basic than it was on the previous cycle when the upper potential limit was $+0.8 \mathrm{~V}$ and all of the film had been oxidized. Thus the anodic peak at $-0.3 \mathrm{~V}$ is now rather small. This positive scan $(\cdots \cdots)$ was then reversed at an upper potential limit of $0 \mathrm{~V}(---)$, causing a further reduction of both the cathodic and anodic peaks at ca. $-0.3 \mathrm{~V}$. At this stage, the solution within the oxide would have equilibrated with the bulk solution and, now, at a near-neutral $\mathrm{pH}$, the oxide would be in the fully reduced state, as $E^{\circ}$ ' would have increased to ca. $+0.1 \mathrm{~V}$. Therefore, little electrochemical response is observed at potentials below $0 \mathrm{~V}$.

In aqueous $\mathrm{LiClO}_{4}$ (Fig. 2B), the voltammogram of $\mathrm{Ir}$ oxide is significantly different from that described above. The main peaks at ca. $+0.7 \mathrm{~V}$ (anodic), +0.71 $\mathrm{V}$ (cathodic) and $-0.38 \mathrm{~V}$ (cathodic) are smaller than the corresponding peaks in Fig. 2A, while the anodic peak at $-0.18 \mathrm{~V}$ is greatly enlarged. Reversing the positive scan at $+0.3 \mathrm{~V}(\cdots \cdots)$, prior to the anodic wave at ca. $+0.7 \mathrm{~V}$, shows that this enlarged wave is reversible. This wave did not diminish significantly during three cycles of potential with an upper potential limit of $+0.3 \mathrm{~V}$ or less, indicating that it is insensitive to $\mathrm{pH}$ changes within the oxide. It cannot therefore be due to the process responsible for the anodic peak at $-0.28 \mathrm{~V}$ in aqueous $\mathrm{Et}_{4} \mathrm{NClO}_{4}$.

The voltammogram shown in Fig. $2 \mathrm{~B}$ can be regarded as similar to that in Fig. $2 \mathrm{~A}$, but with an additional reversible wave at ca. $-0.2 \mathrm{~V}$. We propose that this new wave is due to the insertion and expulsion of $\mathrm{Li}^{+}$with reduction and oxidation, respectively, of the oxide.

Figure $2 \mathrm{C}$ shows that changing the metal ion from $\mathrm{Li}^{+}$to $\mathrm{Na}^{+}$has little effect on the voltammogram. Similar voltammograms were also obtained with $\mathrm{K}^{+}$and $\mathrm{Cs}^{+}$.

\section{Ion analysis and $\mathrm{pH}$ determination}

The results of the ion analysis $\left(\mathrm{F}^{-}, \mathrm{Li}^{+}\right.$and $\left.\mathrm{K}^{+}\right)$and the $\mathrm{pH}$ measurement experiments are presented in Table 1 . In all of the ion analysis experiments (Experiments 1, 2, 4, 5, 10, 11 and 12), a minimum of two experiments were 
TABLE 1

Ionic content of Ir oxide films after elećtrochemical cycling in various aqueous electrolyte solutions

\begin{tabular}{|c|c|c|c|c|c|}
\hline \multirow[t]{2}{*}{ Exp. } & \multirow[t]{2}{*}{ Electrolyte } & \multirow[t]{2}{*}{$\mathrm{pH}^{\mathrm{a}}$} & \multirow[t]{2}{*}{$\begin{array}{l}\text { Ion } \\
\text { measured }\end{array}$} & \multicolumn{2}{|c|}{$\begin{array}{l}\text { Number of ions/number of } \\
\text { electrons }{ }^{\mathrm{b}, \mathrm{c}}\left(\equiv \mathrm{ion} / e^{-} \equiv \text { ion } / \mathrm{Ir}\right)\end{array}$} \\
\hline & & & & $\operatorname{Ir}(\mathrm{IV})^{\mathrm{d}}$ & $\operatorname{Ir}(\mathrm{III})^{\mathrm{d}}$ \\
\hline 1 & $0.1 \mathrm{M} \mathrm{KF}$ & -7 & $\mathrm{~F}^{-}$ & $\begin{array}{l}0.05 \pm 0.02 \\
(0)\end{array}$ & $\begin{array}{l}0.14 \pm 0.04 \\
(0.05)\end{array}$ \\
\hline 2 & $0.1 \mathrm{M} \mathrm{KF}$ & $7-8$ & $\mathrm{~K}^{+}$ & $\begin{array}{l}0.28 \pm 0.10 \\
(0.2)\end{array}$ & $\begin{array}{l}0.09 \pm 0.07 \\
(0)\end{array}$ \\
\hline $3^{\mathrm{e}}$ & $0.1 \mathrm{M} \mathrm{KF}$ & $7.1-8.5$ & $\mathrm{H}^{+}$ & \multicolumn{2}{|c|}{$1.21 \pm 0.03^{\mathrm{f}}$} \\
\hline 4 & $0.2 M \mathrm{HF}$ & -2 & $\mathrm{~F}^{-}$ & $\begin{array}{l}0.08 \\
(0)\end{array}$ & $\begin{array}{c}0.47 \\
(0.4)\end{array}$ \\
\hline 5 & $0.1 M \mathrm{KOH}$ & -13 & $\mathrm{~K}^{+}$ & $\begin{array}{l}0.58 \pm 0.01 \\
(0.6)\end{array}$ & $\begin{array}{l}0.23 \pm 0.04 \\
(0.2)\end{array}$ \\
\hline $6^{\mathrm{e}}$ & $0.1 \mathrm{M} \mathrm{Et}_{4} \mathrm{NClO}_{4}$ & $8.2-8.9$ & $\mathrm{H}^{+}$ & \multicolumn{2}{|c|}{$0.98 \pm 0.04^{\mathrm{f}}$} \\
\hline $7^{e}$ & $0.1 M \mathrm{LiClO}_{4}$ & $8.5-9.0$ & $\mathrm{H}^{+}$ & \multicolumn{2}{|c|}{$0.93 \pm 0.02^{f}$} \\
\hline $8^{e}$ & $0.1 \mathrm{M} \mathrm{KClO}_{4}$ & $4.8-5.5$ & $\mathrm{H}^{+}$ & \multicolumn{2}{|c|}{$1.02 \pm 0.06^{\mathrm{f}}$} \\
\hline $9^{\mathrm{e}}$ & $0.1 \mathrm{M} \mathrm{KClO}_{4}$ & $8.1-9.2$ & $\mathrm{H}^{+}$ & \multicolumn{2}{|c|}{$1.05 \pm 0.08^{\mathrm{f}}$} \\
\hline $10^{\mathrm{e}}$ & $0.1 M \mathrm{LiClO}_{4}$ & $\sim 8$ & $\mathrm{Li}^{+}$ & $\begin{array}{l}0.05 \pm 0.02 \\
(0)\end{array}$ & $\begin{array}{l}0.04 \pm 0.01 \\
(0)\end{array}$ \\
\hline 11 & $0.1 \mathrm{M} \mathrm{LiClO}_{4}$ & $\sim 8$ & $\mathrm{Li}^{+}$ & $\begin{array}{l}<0.01 \\
(0)\end{array}$ & $\begin{array}{l}0.22 \\
(0.2)\end{array}$ \\
\hline 12 & $0.1 \mathrm{M} \mathrm{KClO}_{4}$ & $\sim 7$ & $\mathrm{~K}^{+}$ & $\begin{array}{l}0.04 \\
(0)\end{array}$ & $\begin{array}{l}0.20 \pm 0.04 \\
(0.1)\end{array}$ \\
\hline
\end{tabular}

a The $\mathrm{pH}$ ranges for Experiments 3 and 6-9 reflect the magnitude of the changes during oxidation and reduction.

b Where multiple results have been averaged, the range is given as the standard deviation.

${ }^{c}$ In parentheses, the ion $/ e^{-}$ratios have been corrected for electrolyte in pores (see text, eqn. 4).

d Form of oxide.

${ }^{\text {e }}$ Stirred electrolyte solution.

${ }^{f}$ Number of protons released or consumed per electron, for complete oxidation or reduction, respectively.

performed for each ion, in each electrolyte. In Experiments 4 and 11, the initial measurements were less precise than the second measurements and therefore are not included in the data in Table 1 . These initial measurements were, however, in agreement with the reported results.

A rigorous interpretation of the results of the $\mathrm{K}^{+}, \mathrm{Li}^{+}$and $\mathrm{F}^{-}$analysis is expected to be complicated by the contribution due to any electrolyte which was present within the pores of the oxide film. The results of Experiments 1 and 2, which show that both $\mathrm{K}^{+}$and $\mathrm{F}^{-}$are present within the oxide in both the oxidized and reduced forms, may be taken as evidence of this. A correction for the electrolyte (MX) within the pores can be made if it is assumed that the ionic product of the electrolyte is the same within the oxide film as it is in the bulk solution:

$\left[\mathrm{M}^{+}\right]_{\mathrm{ox}}\left[\mathrm{X}^{-}\right]_{\mathrm{ox}}=c^{2}$

where $\left[\mathrm{M}^{+}\right]_{\mathrm{ox}}$ and $\left[\mathrm{X}^{-}\right]_{\mathrm{ox}}$ are the concentrations of $\mathrm{M}^{+}$and $\mathrm{X}^{-}$within the oxide, 
including both counter-ions and the ions of the electrolyte within pores, and $c$ is the bulk electrolyte concentration. An expression for the ion to $\mathrm{Ir}$ ratios $(\mathrm{M} / \mathrm{Ir}$ and $\mathrm{X} / \mathrm{Ir}$ ) presented in Table 1 can easily be obtained from eqn. (3), where [Ir] depicts the concentration of Ir sites within the oxide film:

$(\mathrm{M} / \mathrm{Ir})(\mathrm{X} / \mathrm{Ir})=(c /[\mathrm{Ir}])^{2}$

Application of eqn. (4) to the data from Experiments 1 and 2 gives a value of close to $0.9 \mathrm{M}$ for the Ir concentration within both the oxidized and reduced forms of the oxide film. This is a reasonable value, considering that the dry density of these films is ca. $2 \mathrm{~g} \mathrm{~cm}^{-3}[9,10]$ ([Ir] $\sim 7 M$ ) and that they appear to contract substantially during drying $[9,14]$, and hence would be significantly less concentrated when wet.

Using eqn. (4) and assuming that $[\mathrm{Ir}]=0.9 \mathrm{M}$ and that $\left[\mathrm{M}^{+}\right]=\left[\mathrm{X}^{-}\right]$within the oxide pores, the ion/Ir ratios have been corrected for electrolyte in the pores of the oxide. These corrected ratios are given in parentheses in Table 1. Consider first the results for $0.1 \mathrm{M}$ KF (Experiments 1-3), where the involvement of all of the ions present $\left(\mathrm{K}^{+}, \mathrm{F}^{-}\right.$and $\mathrm{H}^{+}\left(\right.$or $\left.\left.\mathrm{OH}^{-}\right)\right)$has been monitored. The $\mathrm{pH}$ change accompanying reduction of Ir oxide in this medium indicates that 1.2 protons are inserted into the oxide (or $\mathrm{OH}^{-}$ions expelled) for each electron injected, i.e. for each $\mathrm{Ir}$ center (Experiment 3). This requires that the net charge on the oxide increases by +0.2 per Ir atom during reduction from $\operatorname{Ir}(\mathrm{IV})$ to $\operatorname{Ir}(\mathrm{III})$. Experiments 1 and 2 show that this increase in net charge is compensated mainly by the expulsion of $\mathrm{K}^{+}$ions during reduction.

The empirical formula of Ir oxide films grown in $0.5 M \mathrm{H}_{2} \mathrm{SO}_{4}$ has been determined to be $\mathrm{IrO}_{2} \cdot 3 \mathrm{H}_{2} \mathrm{O}$ [9]. We can therefore represent the electrochemical reduction of Ir oxide in $0.1 M \mathrm{KF}$ by:

$$
\begin{gathered}
\mathrm{K}^{+}\left[\mathrm{Ir}_{5} \mathrm{O}_{10}(\mathrm{OH}) \cdot 14 \mathrm{H}_{2} \mathrm{O}\right]^{-}+5 e^{-}+6 \mathrm{H}_{2} \mathrm{O} \\
=\mathrm{Ir}_{5} \mathrm{O}_{5}(\mathrm{OH})_{5} \cdot 15 \mathrm{H}_{2} \mathrm{O}+\mathrm{K}^{+}+6 \mathrm{OH}^{-}
\end{gathered}
$$

where the minor involvement of $\mathrm{F}^{-}$(Experiment 1 ) has been neglected for simplicity. Reaction (5) has been written arbitrarily in terms of hydroxide ion expulsion rather than proton insertion, since it is not possible to distinguish between these two mechanisms on the basis of the results presented here.

In $0.2 M \mathrm{HF}$, the electrochemical reaction of Ir oxide is somewhat different. The $\mathrm{F}^{-}$content of the oxidized form of the oxide ( 0.08 ions/Ir, Experiment 4$)$ is below the background level estimated using eqn. (4) for Ir oxide in $0.2 \mathrm{M} \mathrm{HF}$ (estimated to be $0.2 \mathrm{~F}^{-} / \mathrm{Ir}$ ), indicating that the oxide may be slightly anionic in this state. The reduced form of the oxide contains more $\mathrm{F}^{-}$ions than the background level, indicating that the oxide is cationic. The electrochemical reduction of Ir oxide in 0.2 $M$ HF can therefore be approximately represented by:

$\left(\mathrm{IrO}_{2} \cdot 3 \mathrm{H}_{2} \mathrm{O}\right)_{5}+5 e^{-}+7 \mathrm{H}^{+}+2 \mathrm{~F}^{-}=\left[\mathrm{Ir}_{5} \mathrm{O}_{3}(\mathrm{OH})_{7} \cdot 15 \mathrm{H}_{2} \mathrm{O}\right]^{2+}\left(\mathrm{F}^{-}\right)_{2}$

where $\left(\mathrm{IrO}_{2} \cdot 3 \mathrm{H}_{2} \mathrm{O}\right)_{5}$ may be dissociated to some extent:

$\left(\mathrm{IrO}_{2} \cdot 3 \mathrm{H}_{2} \mathrm{O}\right)_{5}=\left[\mathrm{Ir}_{5} \mathrm{O}_{10}(\mathrm{OH})_{n} \cdot(15-n) \mathrm{H}_{2} \mathrm{O}\right]^{n-}+n \mathrm{H}^{+}$ 
Reaction (6) involves the insertion of $1.4 \mathrm{H}^{+}$per Ir during oxide reduction, i.e. 82 $\mathrm{mV} / \mathrm{pH}$ unit, but this cannot be tested by our methods in this low $\mathrm{pH}$ range. It should be noted that the $1.4 \mathrm{H}^{+} / \mathrm{Ir}$ ratio obtained in acidic solutions is not in agreement with ref. 4 , where it is reported that only $0.77 \mathrm{D}^{+}$per Ir are inserted during the reduction of Ir oxide in aqueous $\mathrm{D}_{2} \mathrm{SO}_{4}$. However, the latter result was obtained by Rutherford Backscattering of vacuum dried Ir oxide films. By analogy with reaction (6), if the reduced form of the oxide in $\mathrm{D}_{2} \mathrm{SO}_{4}$ were $\left[\operatorname{Ir}_{5} \mathrm{O}_{3}(\mathrm{OH})_{7}\right.$. $15 \mathrm{H}_{2} \mathrm{O}^{2+}\left(\mathrm{SO}_{4}^{2-}\right)$, then decomposition to $\mathrm{Ir}_{5} \mathrm{O}_{5}(\mathrm{OH})_{5}$ with the loss of $\mathrm{H}_{2} \mathrm{SO}_{4}$ and $\mathrm{H}_{2} \mathrm{O}$ could occur under these conditions. We feel that the analysis presented in this paper is more likely to reflect the true state of the oxide under the conditions of the electrochemical experiments.

The results of the $\mathrm{K}^{+}$analysis of Ir oxide that had been cycled electrochemically in $0.1 \mathrm{M} \mathrm{KOH}$ (Experiment 5) indicate that both forms of the oxide contain $\mathrm{K}^{+}$. This shows that both forms of the oxide are anionic under these conditions, with the oxidized form being more highly charged than the reduced form. Reaction (8) can be used to represent approximately the electrochemistry of Ir oxide in $0.1 \mathrm{M} \mathrm{KOH}$. It shows that a ca. $82 \mathrm{mV} / \mathrm{pH}$ dependence would be anticipated in this solution:

$$
\begin{aligned}
& \left(\mathrm{K}^{+}\right)_{3}\left[\mathrm{Ir}_{5} \mathrm{O}_{10}(\mathrm{OH})_{3} \cdot 12 \mathrm{H}_{2} \mathrm{O}\right]^{3-}+5 e^{-}+7 \mathrm{H}_{2} \mathrm{O} \\
& =\left(\mathrm{K}^{+}\right)\left[\mathrm{Ir}_{5} \mathrm{O}_{6}(\mathrm{OH})_{4} \cdot 15 \mathrm{H}_{2} \mathrm{O}\right]^{-}+2 \mathrm{~K}^{+}+7 \mathrm{OH}^{-}
\end{aligned}
$$

The results obtained in near-neutral $\mathrm{MClO}_{4}$ solutions (Experiments 6-12) are somewhat different from the results for neutral KF (Experiments 1-3). These differences may be due to a variation in the $\mathrm{p} K_{\mathrm{a}}$ of the oxide with changes in the nature of the anions present. The $\mathrm{pH}$ measurements (Experiments 6-9) and $\mathrm{M}^{+}$ analysis (Experiment 10) for stirred solutions (see below) indicate that one electron per Ir and no $\mathrm{M}^{+}$is involved in the electrochemistry of the oxide in $\mathrm{MClO}_{4}$ solutions. The reaction

$\mathrm{IrO}_{2} \cdot 3 \mathrm{H}_{2} \mathrm{O}+e^{-}+\mathrm{H}_{2} \mathrm{O}=\mathrm{IrO}(\mathrm{OH}) \cdot 3 \mathrm{H}_{2} \mathrm{O}+\mathrm{OH}^{-}$

represents the electrochemistry of Ir oxide under these conditions.

From reactions (5)-(9), the $\mathrm{pH}$ dependence of the formal reduction/oxidation potential of Ir oxide can be predicted. A pH dependence of $>82$ (reactions 6 and 7), 59 (reaction 9), 70 (reaction 5) and 82 (reaction 8 ) $\mathrm{mV} / \mathrm{pH}$ unit would be expected at approximate $\mathrm{pHs}$ of $2,7\left(\mathrm{MClO}_{4}\right), 8(\mathrm{KF})$ and 13 , respectively. Changes in the slope of a $E^{\circ}$ vs. $\mathrm{pH}$ plot would be expected at $\mathrm{pH}$ values where either form of the oxide changes its net ionic charge. For example, between $\mathrm{pH} 8$ and 2, the oxidized form of Ir oxide changes from being uncharged to being cationic.

These predictions are not readily compatible with the reported ca. $90 \mathrm{mV} / \mathrm{pH}$ dependence [3] of the main redox wave of Ir oxide. However, the formal potential measured from the main redox wave position is for only one type of Ir site within the oxide film. The complex shape of voltammograms of Ir oxide (Fig. 1), and the fact that a varying amount of charge is passed up to the main redox wave as a function of solution $\mathrm{pH}$, indicate clearly that there are a variety of different sites within the oxide which have different formal potentials. The above predictions, 


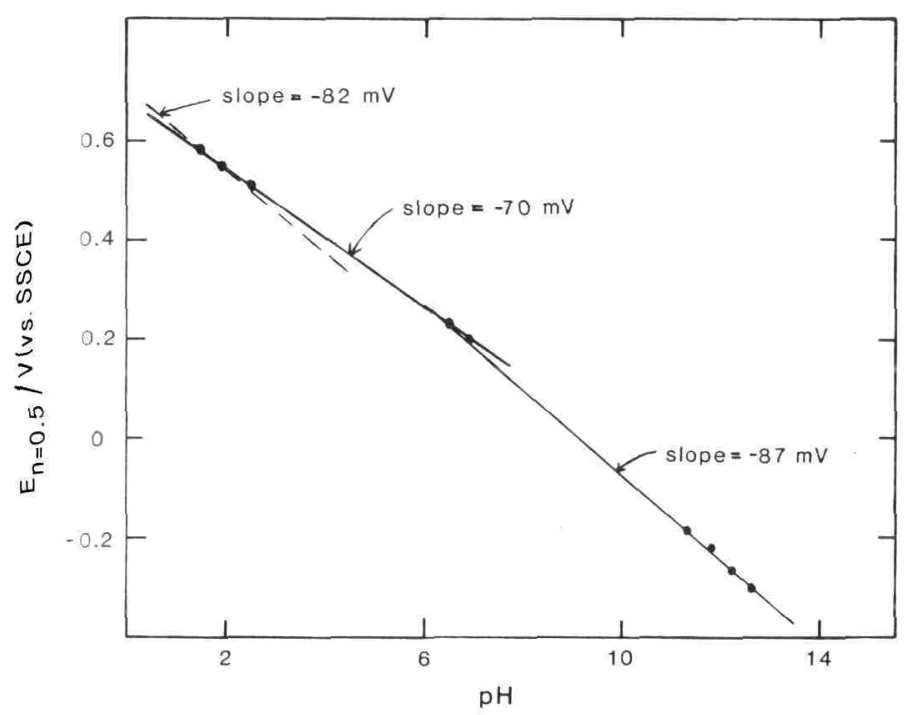

Fig. 3. Plot of $E_{n=0.5}$ vs. $\mathrm{pH}$ for a hydrous Ir oxide film (ca. $0.5 \mu \mathrm{m}$ thick) in $1 M \mathrm{KNO}_{3}$ containing phosphate buffer.

based upon analytical results, refer to the average formal potential of all of the sites. This average formal potential is the potential at which the oxide is oxidized to the extent of $0.5 e^{-} / \operatorname{Ir}$ (relative to the fully reduced form), $E_{n=0.5}$.

Figure 3 shows a plot of $E_{n=0.5}$ vs. $\mathrm{pH}$ for an Ir oxide film in $1 M \mathrm{KNO}_{3}$ containing appropriate amounts of $\mathrm{H}_{3} \mathrm{PO}_{4}$ and $\mathrm{KOH}$. The film was grown in $0.5 \mathrm{M}$ $\mathrm{H}_{2} \mathrm{SO}_{4}$, where it is known that the oxide is oxidized to the extent of $1 e^{-} / \mathrm{Ir}$ at $E_{n=1}=+0.92 \mathrm{~V}$ [9]. The charge required for $n=0.5$, i.e. to oxidize one-half of all of the Ir sites, could thus be determined from a voltammogram of the film in this growth medium. $E_{n=0.5}$ could then be obtained in $\mathrm{KNO}_{3}$ solutions buffered to various $\mathrm{pHs}$ from voltammograms of the oxide obtained in these solutions.

The data shown in Fig. 3 do not fit a single straight line and the average change in $E_{n=0.5}$ with $\mathrm{pH}(80 \mathrm{mV} / \mathrm{pH}$ unit $)$ is less than the change in potential of the major redox wave $(84 \mathrm{mV} / \mathrm{pH}$ unit for this set of data). Also, there is clearly a discontinuity in the dependence of $E_{n=0.5} \mathrm{On} \mathrm{pH}$ in the $\mathrm{pH}$ range between $\mathrm{pH} 2$ and 7 . These results are consistent with the predictions of reactions (5)-(9).

$M^{+}$insertion

The results of Experiments 11 and 12 in Table 1 show clearly that $\mathrm{M}^{+}$insertion can occur during Ir oxide reduction in neutral $\mathrm{LiClO}_{4}$ and $\mathrm{KClO}_{4}$ solutions, since there is significantly more $\mathrm{M}^{+}$in the reduced form of the oxide than in the oxidized form. In these two experiments, the solution was not stirred and the electrode was left in the cell at open circuit for 2 min before rinsing and extraction of the $\mathrm{M}^{+}$. In other experiments, when the electrode was immediately removed from the cell after reduction of the oxide, higher $\mathrm{M}^{+}$contents were found. 


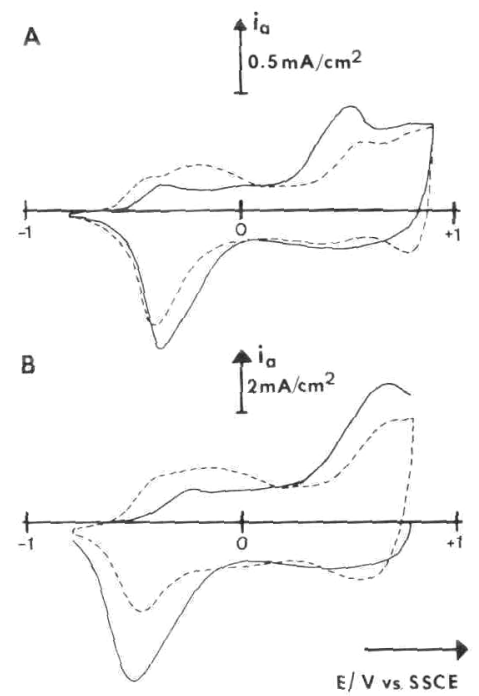

Fig. 4. Cyclic voltammograms of hydrous Ir oxide films (ca. $1 \mu \mathrm{m}$ thick) in $0.1 M \mathrm{LiClO}_{4}$ (A) (scan rate $=10 \mathrm{mV} / \mathrm{s}$ ) and $0.1 M \mathrm{KClO}_{4}(\mathrm{~B})$ (scan rate $=100 \mathrm{mV} / \mathrm{s}$ ). Dashed lines are conventional voltammograms obtained in unstirred solutions. The solid line in A shows the effect of stirring the solution. The solid line in B shows the effect of holding the potential at each limit for $5 \mathrm{~min}$.

In Experiment 10, the cell solution was stirred while the electrode was left in the cell at open circuit for $3 \mathrm{~min}$ before rinsing and extraction. Under these conditions, neither form of the oxide had a $\mathrm{M}^{+}$content significantly above the estimated background level ( 0.11 ion/Ir, eqn. 4). Clearly, stirring of the cell solution results in loss of the $\mathrm{M}^{+}$which was initially inserted into the oxide during its reduction.

Monitoring of the $\mathrm{pH}$ of the cell solution in these experiments revealed that the $\mathrm{pH}$ could be equilibrated in ca. 3 min with stirring, whereas the system was still far from equilibrium after $5 \mathrm{~min}$ if the solution was not stirred.

Presumably, the high $\mathrm{pH}$ within the oxide film immediately following its reduction prevents protonation of the reduced oxide and consequently, metal ions enter the film, compensating for the electronic charge injection. As the $\mathrm{pH}$ returns to near-neutral conditions with stirring and time, protonation of the oxide occurs and the $\mathrm{M}^{+}$counter ions are expelled. This behavior can be represented by combining reactions (8) and (9):

$$
\begin{aligned}
& \mathrm{Ir}_{5} \mathrm{O}_{10} \cdot 15 \mathrm{H}_{2} \mathrm{O}+5 e^{-}+4 \mathrm{H}_{2} \mathrm{O}+\mathrm{M}^{+} \rightarrow\left(\mathrm{M}^{+}\right)\left[\mathrm{Ir}_{5} \mathrm{O}_{6}(\mathrm{OH})_{4} \cdot 15 \mathrm{H}_{2} \mathrm{O}\right]^{-}+4 \mathrm{OH}^{-} \\
& \mathrm{pH} \sim 7 \quad+\mathrm{H}^{+}+\mathrm{M}^{+} \quad \mathrm{pH} \sim 13 \\
& \mathrm{Ir}_{5} \mathrm{O}_{5}(\mathrm{OH})_{5} \cdot 15 \mathrm{H}_{2} \mathrm{O}
\end{aligned}
$$

These conclusions are supported by the voltammograms shown in Fig. 4. Figure

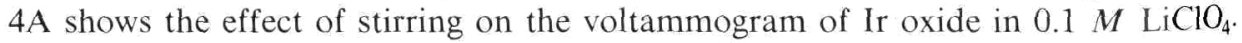
Stirring causes a significant decrease in the anodic peak at $-0.20 \mathrm{~V}$, which indicates 
$\mathrm{Li}^{+}$expulsion. Figure 4B shows linear sweep and cyclic voltammograms of Ir oxide in $0.1 \mathrm{M} \mathrm{KClO}_{4}$. Holding the potential at $-0.70 \mathrm{~V}(-\ldots)$ results in a much smaller $\mathrm{K}^{+}$expulsion peak at $-0.15 \mathrm{~V}$, as $\mathrm{H}^{+}$replaces $\mathrm{K}^{+}$in the oxide with time.

CONCLUSIONS

The quantitative analysis of the ions involved in the electrochemistry of hydrous iridium oxide has yielded a much clearer picture of the reactions taking place during oxide charging and discharging. By conducting experiments over a wide range of $\mathrm{pH}$ and with various electrolytes, we have been able to identify the reactions occurring and the ions which are involved in them over the $\mathrm{pH}$ range 2 to 13 .

The charge on both the oxidized and reduced forms of Ir oxide has been found to change with $\mathrm{pH}$. The reduced form is cationic at $\mathrm{pH} 2$, approximately neutral at $\mathrm{pH}$ 7 and slightly anionic at $\mathrm{pH} 13$. The oxidized form is neutral or slightly anionic between $\mathrm{pH} 2$ and 9 and is significantly anionic at $\mathrm{pH} 13$. These changes of the charge of Ir oxide cause the $\mathrm{pH}$ dependence of the formal potential of the oxide to vary with $\mathrm{pH}$. At $\mathrm{pH}$ values between 2 and 7 , the $\mathrm{pH}$ dependence changes from ca. 80 to ca. $70 \mathrm{mV} / \mathrm{pH}$ unit. Between $\mathrm{pH} 7$ and 11, the dependence changes from ca. 70 to ca. $90 \mathrm{mV} / \mathrm{pH}$ unit.

In acid solutions, anions are injected into the oxide during its reduction, as the oxide is cationic at low $\mathrm{pH}$. In alkaline solutions, cations are present to a significant extent in oxidized Ir oxide, and to a smaller extent, in the reduced form. In unbuffered neutral solutions, a transient insertion of metal cations occurs during oxide reduction as a result of $\mathrm{pH}$ changes which occur within the oxide.

\section{ACKNOWLEDGEMENT}

This work was supported by the Natural Sciences and Engineering Research Council of Canada and by Allied Canada Inc., to whom we are grateful.

\section{REFERENCES}

1 S. Gottesfeld and J.D.E. McIntyre, J. Electrochem. Soc., 126 (1979) 742.

2 G. Beni, C.E. Rice and J.L. Shay, J. Electrochem. Soc., 127 (1980) 1342.

3 L.D. Burke and D.P. Whelan, J. Electroanal. Chem., 124 (1981) 333.

4 J.D.E. McIntyre, S. Basu, W.F. Peck, Jr., W.L. Brown and W.M. Augustyniak, Phys. Rev. B, 25 (1982) 7242.

5 M.F. Yuen, I. Lauks and W.C. Dautremont-Smith, Solid State Ionics, 11 (1983) 19.

6 L.D. Burke and D.P. Whelan, J. Electroanal. Chem., 162 (1984) 121.

7 S.H. Glarum and J.H. Marshall, J. Electrochem. Soc., 127 (1980) 1467.

8 R.D. Armstrong, A.K. Sood and M. Moore, J. Appl. Electrochem., 15 (1985) 603.

9 P.G. Pickup and V.I. Birss, J. Electrochem. Soc., in press.

10 J.D.E. McIntyre, W.F. Peck, Jr. and S. Nakahara, J. Electrochem. Soc., 127 (1980) 1264.

11 L.D. Burke and R.A. Scannell, J. Electroanal. Chem., 175 (1984) 119.

12 L.D. Burke, J.K. Mulcahy and D.P. Whelan, J. Electroanal. Chem., 163 (1984) 117.

13 P.G. Pickup and V.I. Birss, J. Electrochem. Soc., in press.

14 J. Mozota and B.E. Conway, J. Electrochem. Soc., 128 (1981) 2142. 